\title{
CD40 expression on human pancreatic duct cells: role in nuclear factor-kappa B activation and production of pro-inflammatory cytokines
}

\author{
O. Vosters ${ }^{1,2}$ • C. Beuneu ${ }^{1,2}$ • N. Nagy ${ }^{3}$ B. Movahedi ${ }^{2,4}$ • E. Aksoy ${ }^{1}$ I. Salmon ${ }^{3}$ - D. Pipeleers ${ }^{2,4} \cdot$ M. Goldman $^{1,2}$ • \\ V. Verhasselt ${ }^{1,2}$ \\ ${ }^{1}$ Laboratory of Experimental Immunology, Brussels Free University, Erasme Hospital, Brussels, Belgium \\ 2 JDRF Center for Beta Cell Therapy in Europe, Coordination Core, Brussels, Belgium \\ ${ }^{3}$ Laboratory of Pathology, Brussels Free University, Belgium \\ ${ }^{4}$ Diabetes Research Center, Brussels Free University, Belgium
}

\section{Abstract}

Aims/hypothesis. Human pancreatic duct cells are closely associated with islet beta cells, and contaminate islet suspensions transplanted in Type 1 diabetes mellitus patients. Activated duct cells produce cytotoxic mediators and possibly contribute to the pathogenesis of Type 1 diabetes mellitus or islet graft rejection. As CD40 transduces activation signals involved in inflammatory and immune disorders, we investigated CD40 expression on duct cells and their response to $\mathrm{CD} 40$ engagement.

Methods. CD40 expression on human pancreatic duct cells was analysed by flow cytometry and immunohistochemical analyses. To assess the function of CD40 expression on duct cells, activation of the transcription factor nuclear factor-kappa B was determined using electrophoretic mobility shift assay and ELISA. Cytokine mRNA levels were quantified by real-time RT-PCR, and protein levels by Luminex technology.

Results. Isolated human pancreatic duct cells and Capan-2 cell lines were found to express constitutive- ly CD40. The expression of CD40 on duct cells was confirmed in vivo on human normal and pathological pancreatic specimens. CD40 ligation on Capan-2 cells induced rapid nuclear factor-kappa B activation, and supershift assays demonstrated that p50/p65 heterodimers and p50/p50 homodimers were present in the activated complexes in the nucleus. This activation was accompanied by tumour necrosis factor- $\alpha$ and interleukin-1 $\beta$ mRNA accumulation. Tumour necrosis factor- $\alpha$ protein secretion was confirmed in CD40-activated Capan-2 cells and in isolated human pancreatic duct cells.

Conclusions/interpretation. Interaction between activated $\mathrm{T}$ lymphocytes expressing CD40 ligand and duct cells expressing CD40 may contribute to the immune responses involved in Type 1 diabetes mellitus and islet graft rejection. Interfering with CD40-mediated duct cell activation could alleviate beta cell damage of immune origin.

Keywords Capan- $2 \cdot$ CD40 - IL-1 $\beta$.

Islet transplantation $\cdot \mathrm{NF}-\kappa \mathrm{B} \cdot$ Pancreatic duct cells . TNF- $\alpha \cdot$ Type 1 diabetes mellitus
Received: 7 October 2003 / Accepted: 16 January 2004

Published online: 19 March 2004

(C) Springer-Verlag 2004

M. Goldman (-

Laboratory of Experimental Immunology,

Brussels Free University, Erasme Hospital,

808 route de Lennik, 1070 Brussels, Belgium

E-mail: mgoldman@ulb.ac.be

Abbreviations: CD40L, CD40 ligand - CK19, cytokeratin 19 . EMSA, electrophoretic mobility shift assay · $\mathrm{mAb}$, monoclonal antibody $\cdot \mathrm{NF}-\kappa \mathrm{B}$, nuclear factor-kappa B $3 \mathrm{~T}_{\mathrm{CD} 40 \mathrm{~L}}, \mathrm{CD} 40 \mathrm{~L}$-transfected fibroblasts .

$3 \mathrm{~T} 6_{\mathrm{CTRL}}$, untransfected fibroblasts

\section{Introduction}

Duct cells are closely associated with beta cells in the human pancreas [1]. There is suggestive evidence that pancreatic ducts are potential sites for beta cell neogenesis $[1,2,3,4,5,6,7]$. Duct cells were also shown to produce nitric oxide [4] and to express MHC class II [3], leading to proposals that they might contribute to beta cell damage in Type 1 diabetes mellitus [8]. In the transplantation setting, islet suspensions prepared from human pancreases contain a high proportion of non-endocrine duct cells $[9,10]$, implying that these cells could affect graft acceptance. Defining the path- 
ways of duct cell activation is therefore relevant to understanding both the pathogenesis of Type 1 diabetes and islet transplantation.

Previous studies have shown that exposure of duct cells to pro-inflammatory cytokines such as IFN- $\gamma$, either alone or in combination with IL-1 $\beta$, led to their stimulation [1, 3, 4]. In particular, we recently observed that IL-1-exposed duct cells synthesise and release TNF- $\alpha$ (B. Movahedi, unpublished results). In addition, duct cells were shown to express CD14, a pattern recognition receptor $[11,12]$ that might allow duct cells to respond to microbial products. In renal, airway or intrahepatic epithelial cells, membrane expression of CD40 molecules was found to transduce activation signals upon interaction with CD154, the CD40 ligand $[13,14,15,16,17,18]$. CD40 is a member of the TNF-receptor family, and was initially described on B cells but subsequently found on a wide variety of cell types including activated monocytes, dendritic cells, endothelial cells, epithelial cells and fibroblasts [19, 20, 21]. The ligand for CD40 (CD40L) is a type II transmembrane protein expressed on stimulated $\mathrm{T}$ cells but also on mast cells, basophils and platelets. A soluble form of CD40L is released from activated platelets or shed from stimulated lymphocytes [21, 22, 23, 24]. CD40-CD154 interactions were shown to play a pivotal role in different T-cell-mediated inflammatory disorders $[20,21,25,26,27]$ and disruption of CD40-CD40L interactions proved to be sufficient to prevent the development and progression of several autoimmune diseases [28, 29] as well as allograft rejection $[21,26]$.

In this work we studied the expression of CD40 on human pancreatic duct cells and then investigated the functional consequences of CD40 ligation at the duct

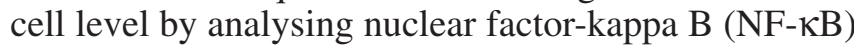
activation, cytokine mRNA accumulation and protein secretion.

\section{Materials and methods}

Cell cultures Human adenocarcinoma cell line (Capan-2) was kindly provided by Dr L. Bouwens (Cell Differentiation Unit, Brussels Free University, Belgium) and was cultured as previously described [30]. Briefly, cells were cultured in McCoy's 5A medium with glutamax-1 (Invitrogen, Merelbeke, Belgium) supplemented with $50 \mathrm{U} / \mathrm{ml}$ penicillin, $50 \mu \mathrm{g} / \mathrm{ml}$ streptomycin (BioWhittaker, Verviers, Belgium) and 10\% FCS (Hyclone, Erembodegem, Belgium). When 80 to $90 \%$ confluence was reached, cells were detached by trypsin/EDTA (Invitrogen; $0.05 \%$ trypsin, $0.53 \mathrm{mmol} / \mathrm{l}$ EDTA) digestion and subcultured at a ratio of $1: 4$.

Human non-endocrine pancreatic duct cells were isolated from pancreases obtained from adult heart-beating organ donors as previously described [4], following guidelines of protocols that were approved by the local ethics committee. The organs were procured by European hospitals affiliated with the Eurotransplant Foundation (Leiden, The Netherlands) and sent to the Human Beta Cell Bank in Brussels (Belgium) for the preparation of isolated fractions. Collagenase digests were separated by Ficoll gradient purification into an islet and an exocrine fraction. This exocrine fraction was cultured in serum-free medium for at least 4 days leading up to a preparation enriched in duct cells (>95\%). Then, cells were dissociated in a calcium-free medium and cultured with $10 \%$ FCS to obtain monolayers. After 2 to 3 days of culture with $10 \%$ FCS, isolated cells were tested for purity. More than $90 \%$ were positive for cytokeratin 19 (CK19) as assessed by immunostaining. This was confirmed by flow cytometry analysis using CD1a, CD3, CD14, CD16 and CD19 monoclonal antibodies (mAbs), excluding a contamination of duct cells in monolayer by dendritic cells, T lymphocytes, monocytes, natural killer cells and B cells respectively.

For CD40 ligation studies, $2.5 \times 10^{5}$ duct cells were co-cultured in a 24 -well plate with $2.5 \times 10^{5}$ mouse fibroblasts transfected with the human CD40L gene. As controls, duct cells were co-cultured with untransfected fibroblasts. Mouse fibroblasts transfected with the human CD40L gene and untransfected mouse fibroblasts were kindly provided by $\mathrm{Dr} \mathrm{K}$. Thielemans.

Flow cytometry analysis Cells were washed in PBS supplemented with $1 \%$ BSA, $0.1 \% \mathrm{NaN}_{3}$ and $10 \%$ pooled human serum, and incubated for $20 \mathrm{~min}$ at $4^{\circ} \mathrm{C}$ with one of the following fluorescein isothiocyanate- or phycoerythrin-conjugated mAbs: anti-HLA-DR IgG2a (Becton-Dickinson, Erembodegem, Belgium), anti-CD80 IgG1 (B7-1; Becton-Dickinson), anti-CD86 IgG2b (B7-2; BD Biosciences Pharmingen, San Diego, Calif., USA), anti-CD40 IgG1 (Biosource International, Camarillo, Calif., USA), anti-CD154 IgG1 (Becton-Dickinson), anti-CD54 IgG1 (Becton-Dickinson) or anti-HLA-A,B,C IgG1 (BectonDickinson), or the corresponding isotype-matched control mAbs. Cell fluorescence was then analysed using a FACScan flow-cytometer (Becton-Dickinson).

Immunohistochemistry studies Immunohistochemical analysis was performed on formalin-fixed, paraffin-embedded pancreatic specimens, including one autoimmune pancreatitis and one well-differentiated ductal adenocarcinoma. 5- $\mu \mathrm{m}$ sections were cut onto coated slides and were deparaffined using routine techniques. After antigen retrieval in EDTA and microwave pretreatment, the sections were incubated with a mouse anti-CD40 $\mathrm{mAb}$ (Novocastra, Merelbeke, Belgium) at a dilution of 1 to 30 . Labelling was detected by streptavidin-biotin-peroxidase complex (Dako, Merelbeke, Belgium). Negative control was obtained by omitting the primary antibody. For CK19 staining, sections were incubated with a human CK19 mAb (clone RCK108; Dako) at a dilution of 1 to 100. Labelling was detected by streptavidin-biotin-peroxidase complex (Dako).

Analysis of $N F-\kappa B$ transcriptional activity Electrophoretic mobility shift assay (EMSA) was performed as previously described [31]. Briefly, Capan-2 cells were incubated for $2 \mathrm{~h}$ under the different conditions tested: in medium alone, with untransfected fibroblasts, or with CD40L-transfected fibroblasts. Nuclear extracts were prepared as previously described [32]. The double-stranded consensus-binding sequences for the EMSA comprised the oligonucleotide 5'-AGTTGAGGGGACTTTCCCAGG-3' for NF- $\kappa B$ and for the mutant $N F-\kappa B$, created with a $\mathrm{G} \rightarrow \mathrm{C}$ substitution. The probe was endlabelled with $\left[\gamma_{-}{ }^{32} \mathrm{P}\right]$ ATP from Amersham Pharmacia Biotech (Roosendaal, The Netherlands) using T4 polynucleotide kinase (Roche Diagnostics, Brussels, Belgium). For the binding reaction, $15 \mu \mathrm{g}$ of the nuclear extract was added to the reaction mixture containing $4 \mu \mathrm{g}$ poly $\mathrm{dI}-\mathrm{dC}$ (Roche Diagnostics), $4 \mu \mathrm{l}$ of binding buffer (10 mmol/l HEPES, $\mathrm{pH} 7.8 ; 50 \mathrm{mmol} / \mathrm{l}$ $\mathrm{KCl} ; 1 \mathrm{mmol} / \mathrm{l}$ EDTA; $5 \mathrm{mmol} / \mathrm{l} \mathrm{MgCl}_{2} ; 10 \%$ glycerol) and 

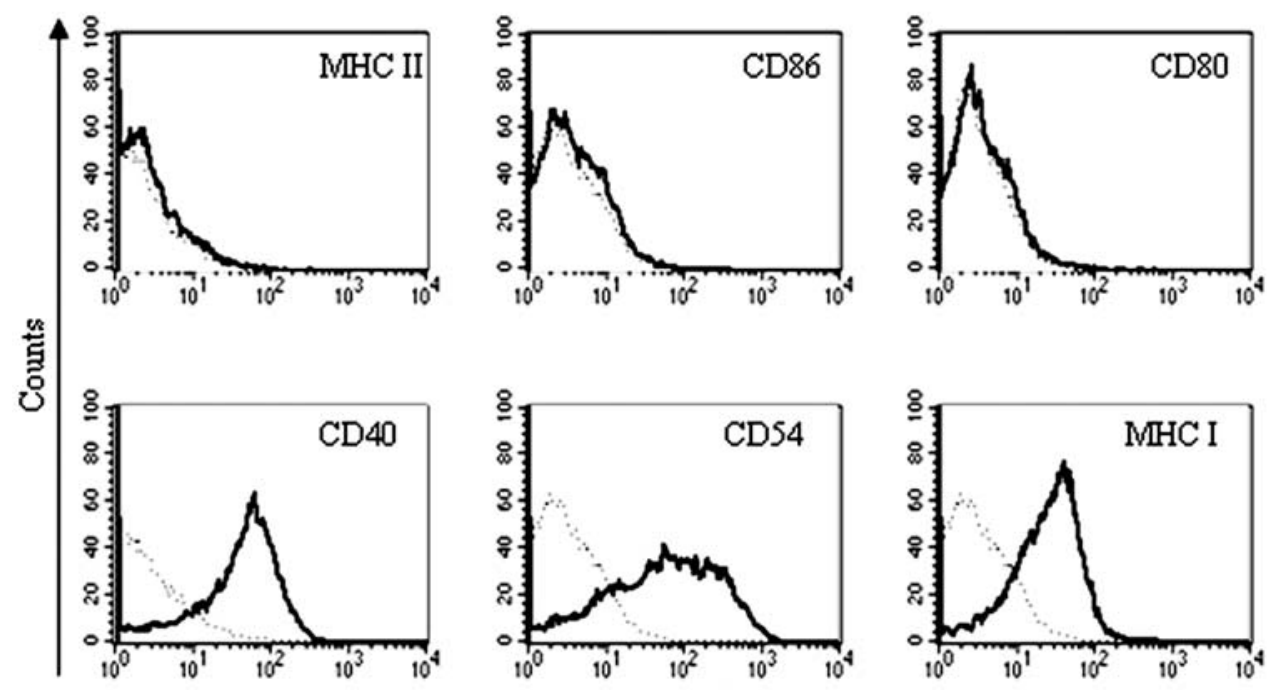

b

Fluorescence intensity
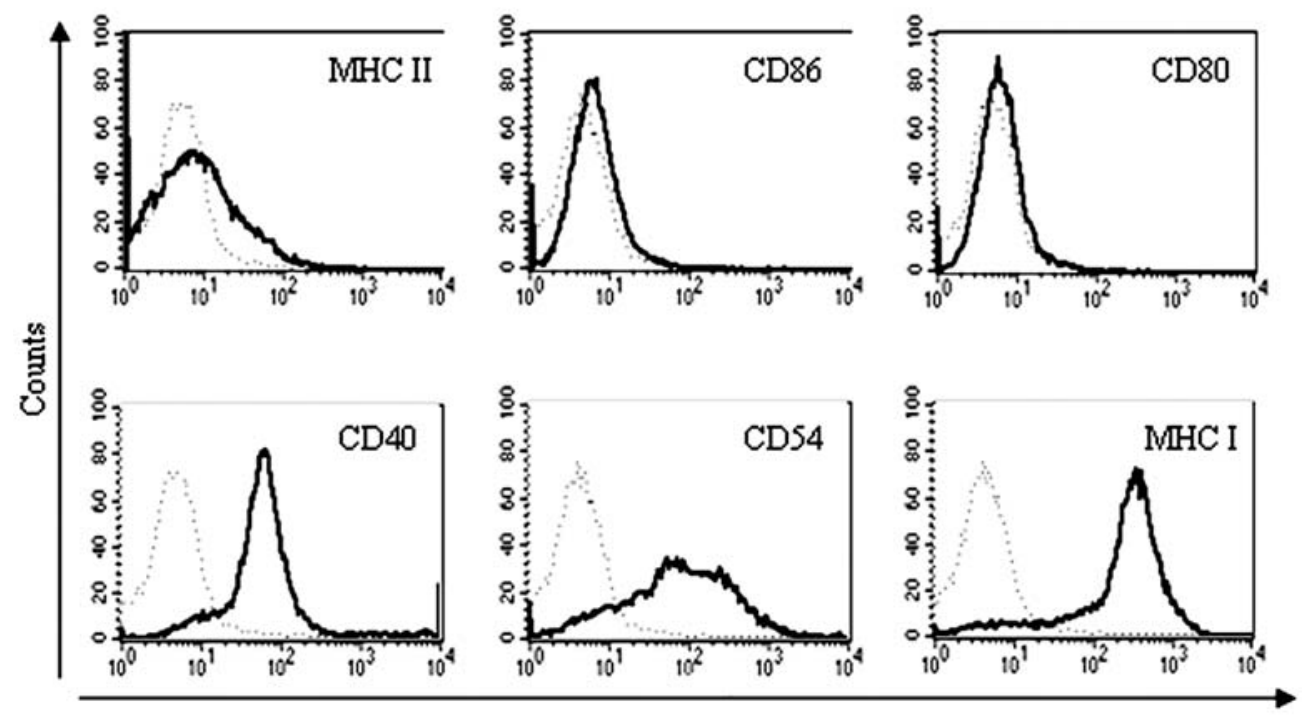

Fluorescence intensity

Fig. 1. Surface molecule expression analysis using flow cytometry on (a) human pancreatic duct cells in monolayer and (b) Capan-2 cell line. Cells were harvested and analysed by flow cytometry after staining with the corresponding monoclonal antibodies. Dotted histograms represent isotypic control staining and bold histograms represent specific labelling. One representative experiment out of five is shown

$30,000 \mathrm{cpm}$ of $\left.{ }^{32} \mathrm{P}\right]$-end-labelled probe in a final volume of $20 \mu \mathrm{l}$. The mixture was left for $15 \mathrm{~min}$ at room temperature. Supershift assays were performed after adding $1 \mu \mathrm{g}$ of murine mAb against RelA/p65 (Santa Cruz Biotechnology, Santa Cruz, Calif., USA) or NF- $\kappa \mathrm{B} 1 / \mathrm{p} 50$ (Upstate Biotechnology, Mundolsheim, France) to the binding reaction for $30 \mathrm{~min}$ at $4^{\circ} \mathrm{C}$. The free and protein-bound oligonucleotides were resolved by electrophoresis on a $7 \%$ polyacrylamide gel in
Tris-borate EDTA buffer. The DNA-protein complexes were detected by autoradiography film (Eastman Kodak, Bornem, Belgium).

In parallel, NF- $\kappa \mathrm{B}$ DNA-binding activity in nuclear extracts was measured using the Trans-AM NF- $\mathrm{BB}$ p65 ELISA kit (Active Motif Europe, Rixensart, Belgium) according to manufacturer's instructions. Briefly, $5 \mu \mathrm{g}$ nuclear extract were added to a 96-well plate to which oligonucleotide containing $\mathrm{NF}-\kappa \mathrm{B}$ consensus-binding site had been immobilised. The NF$\kappa \mathrm{B}$ complex bound to the oligonucleotide was detected by adding a specific $\mathrm{mAb}$ for p65 subunit. A secondary horseradish peroxydase-conjugated $\mathrm{mAb}$ was added and developed with tetramethylbenzidine substrate. After an optimal development time, the reaction was stopped using $\mathrm{H}_{2} \mathrm{SO}_{4}$ $0.5 \mathrm{~mol} / \mathrm{l}$, and absorbance was measured at $450 \mathrm{~nm}$. The specificity of the assay was monitored by competition experiments using NF- $\kappa \mathrm{B}$ wild-type and mutant consensus oligonucleotides provided in the kit. 
Real-time RT-PCR The mRNA content of $2.5 \times 10^{5}$ viable cells was isolated using the MagNA Pure mRNA extraction kit (Roche Applied Science, Brussels, Belgium) on the MagNA Pure instrument following manufacturer's instructions (mRNA I cells, Roche protocol; final elution volume $50 \mu \mathrm{l}$ ). Cytokine mRNA levels were then quantified by real-time RT-PCR on a Lightcycler instrument (Roche Applied Science) as previously described [33]. Primers and probes were synthesised at Biosource Europe (Nivelles, Belgium) using the sequences previously described $[33,34]$. Cytokine mRNA levels were determined according to a standard curve generated from serial dilutions of a purified DNA, allowing expression of the results in mRNA copies per $10^{6}$ mRNA copies of $\beta$-actin.

Cytokine assays TNF- $\alpha$ was measured in cell culture supernatants using Luminex technology (Bio-Rad, Nazareth-Eke, Belgium) and a Fluorokine MAP human TNF- $\alpha$ Kit (R\&D Systems, Abingdon, UK) following manufacturer's instructions. Briefly, $2.5 \times 10^{5}$ ductal cells were cultured in a $24-$ well plate with a final volume of $1 \mathrm{ml}$ for $24 \mathrm{~h}$ either alone or in the presence of $2.5 \times 10^{5} \mathrm{CD} 40 \mathrm{~L}$-transfected or untransfected fibroblasts.

Statistical analysis Data were compared using the non-parametric Wilcoxon's paired test. Results were considered statistically significant with a $p$ value of less than 0.05 .

\section{Results}

Human pancreatic duct cells express CD40 in vitro and in vivo. We investigated the expression on duct cells of surface molecules involved in interactions with $\mathrm{T}$ lymphocytes. As shown in Fig. 1a, primary duct cells were negatively stained for MHC class II and costimulatory molecules (CD80 and CD86), but expressed high levels of CD40, CD54 and MHC class I molecules. A similar phenotype was found on a duct cell line, Capan-2 (Fig. 1b).

To confirm CD40 expression in vivo, immunohistochemical analysis was performed on human pancreatic specimens. In the normal adult pancreas, CD40 was expressed on the ductal epithelium (Fig. 2a) but not on islet beta cells (Fig. 2b). CD40 showed intracytoplasmic positivity both at the luminal and the basal surface of the ductal epithelium. CD40 immunostaining of duct cells was also observed on pathological pancreatic specimens including an autoimmune pancreatitis and a well-differentiated ductal adenocarcinoma (Fig. $2 \mathrm{c}$ and $2 \mathrm{~d}$ respectively). As expected, B lymphocytes in the lymphoid follicules were positively stained by anti-CD40 mAb, providing an internal positive control for the CD40 labelling method (Fig. 2c). In order to ascertain whether CD40 was expressed on ductal epithelial cells, immunohistochemical analysis for CK19, a specific marker for epithelial cells, and for CD40 was performed on serial sections of formalin-fixed, paraffin-embedded human pancreatic specimens. As shown in Fig. 2 (a, c and d), CD40 expression correlated with CK19 expression, confirming that CD40 was indeed expressed on duct cells in
CK19

CD40

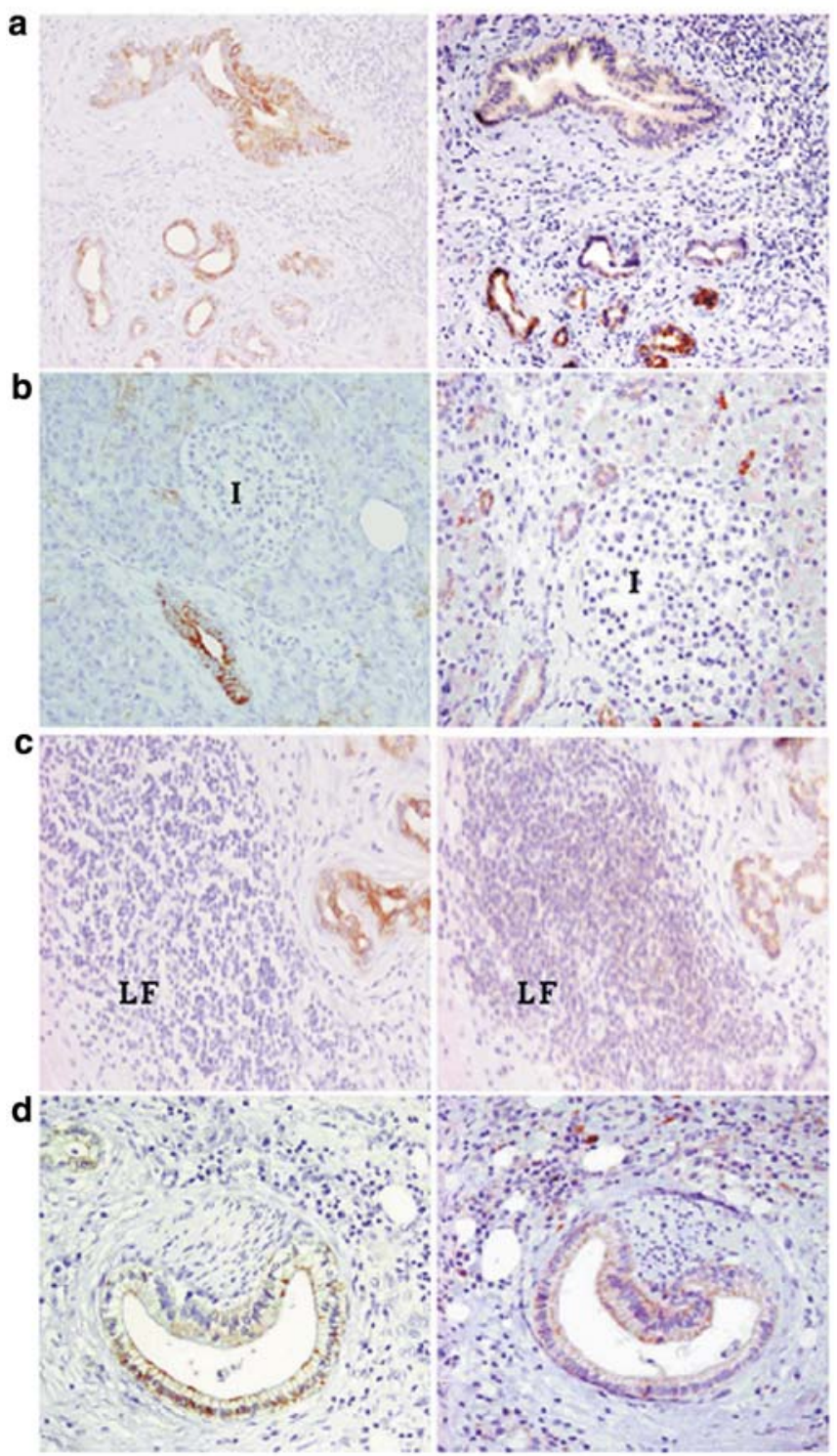

Fig. 2. Immunohistochemical analysis for CK19 and CD40 expression performed on serial sections of formalin-fixed, paraffin-embedded pancreatic specimens. a, b Staining in normal adult pancreas. c. Staining in autoimmune pancreatitis. d Staining in well-differentiated ductal adenocarcinoma. Original magnification: $200 \times$. LF, lymphoid follicules; I, islets of Langerhans

the human pancreas. Negative control obtained by omitting the primary antibody showed no staining for CK19 or CD40 (data not shown).

Ligation of CD40 expressed on Capan-2 induces $N F-\kappa B$ activation. To study the functional relevance of CD40 expression by human pancreatic duct cells, we assessed NF- $\kappa B$ activation in Capan-2 cells co-cultured with fibroblasts overexpressing CD40L (CD154). As shown in Fig. 3a, we observed that Capan-2 cells expressed low NF-אB p65 DNA-binding activity at the basal state, and that their exposure 


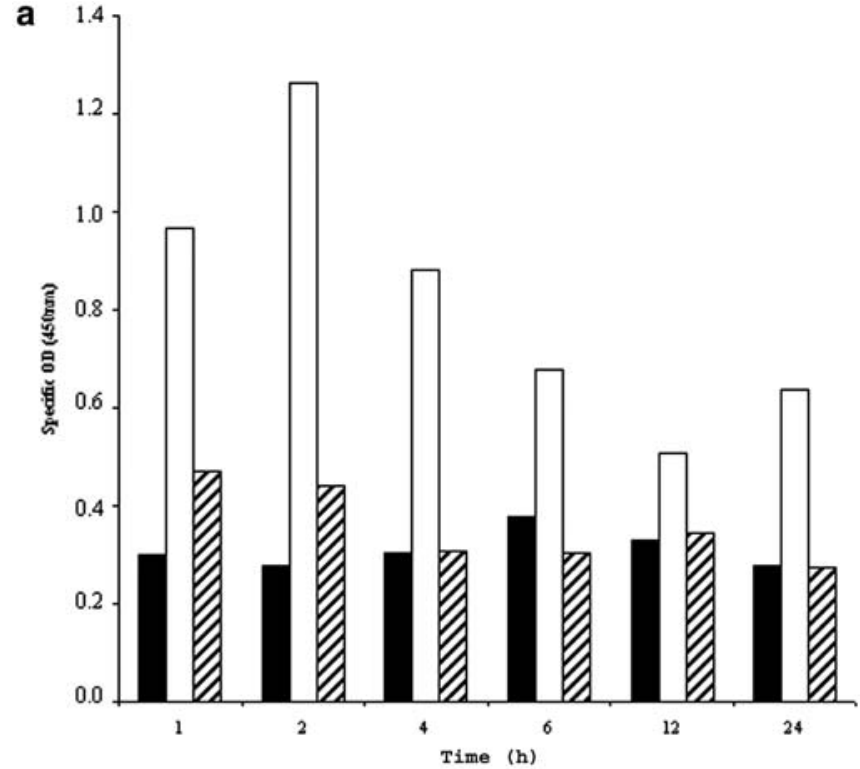

b

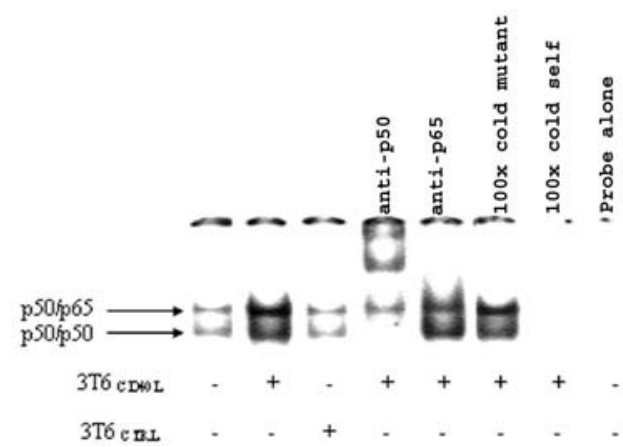

Fig. 3. Assessment of nuclear factor- $\kappa \mathrm{B}(\mathrm{NF}-\kappa \mathrm{B})$ activation in Capan-2 cell line. a Time course determination of $N F-\kappa B$ DNA-binding activity using TransAm transcription factor (p65 subunit) ELISA kit. Optical density values (OD; $450 \mathrm{~nm}$ ) were corrected for background levels. Nuclear extracts were obtained after indicated time intervals for co-culture of $2.5 \times 10^{5}$ Capan- 2 cells alone (black histogram), $2.5 \times 10^{5}$ Capan- 2 cells co-cultured with $2.5 \times 10^{5}$ CD $40 \mathrm{~L}$-transfected fibroblasts $\left(3 \mathrm{~T}_{\mathrm{CD} 40 \mathrm{~L}}\right.$; white histogram) or $2.5 \times 10^{5}$ Capan- 2 cells co-cultured with $2.5 \times 10^{5}$ untransfected fibroblasts $\left(3 \mathrm{~T} 6_{\mathrm{CTRL}}\right.$; hatched histogram). One representative experiment out of three is shown. b NF- $\kappa$ B DNA-binding activity determination using electrophoretic mobility shift assay. Nuclear extracts were obtained after $2 \mathrm{~h}$ co-culture of $2.5 \times 10^{5}$ Capan- 2 cells with $2.5 \times 10^{5}$ CD $40 \mathrm{~L}$-transfected fibroblasts $\left(3 \mathrm{~T} 6_{\mathrm{CD} 40 \mathrm{~L}}\right)$ or untransfected fibroblasts $\left(3 \mathrm{~T}_{\mathrm{CTRL}}\right)$. Where indicated, nuclear extracts were pre-incubated with anti-p50 antibodies, anti-p65 antibodies, mutant probes or self-cold probes. One representative experiment out of three is shown

to $\mathrm{CD} 40 \mathrm{~L}$-transfected fibroblasts $\left(3 \mathrm{~T} 6_{\mathrm{CD} 40 \mathrm{~L}}\right)$ induced a rapid and clear increase in NF- $\mathrm{KB}$ p65 activation. A time course experiment established that p65 subunit activation was optimal after $2 \mathrm{~h}$ of co-culture, followed by a progressive decrease within $24 \mathrm{~h}$. This pattern of NF- $\kappa B$ activation was caused by CD40 ligation, as it was not observed upon coculture of duct cells with untransfected fibroblasts $\left(3 \mathrm{~T} 6_{\mathrm{CTRL}}\right)$.
Table 1. TNF- $\alpha$ production by isolated human pancreatic duct cells after CD40 engagement

\begin{tabular}{llc}
\hline & \multicolumn{2}{l}{$\mathrm{TNF}-\alpha\left(\mathrm{pg} / 10^{6}\right.$ cells $)$} \\
\cline { 2 - 3 } & Experiment 1 & Experiment 2 \\
\hline Unstimulated & 152.54 & 92.06 \\
$+36_{\mathrm{CD} 40 \mathrm{~L}}$ & 652.72 & 226.28 \\
$+36_{\mathrm{CTRL}}$ & 143.74 & 57.30 \\
\hline
\end{tabular}

Isolated human pancreatic duct cells were stimulated with CD40L-transfected $\left(3 \mathrm{~T}_{\mathrm{CD} 40 \mathrm{~L}}\right)$ or untransfected $\left(3 \mathrm{~T} 6_{\mathrm{CTRL}}\right)$ mouse fibroblasts. After $24 \mathrm{~h}$, cell culture supernatants were collected and levels of TNF- $\alpha$ were analysed using Luminex technology. Results expressed as pg/106 cells from two independent experiments performed in duplicate are shown.

This observation was confirmed and extended in EMSA experiments performed on nuclear extracts, as shown in Fig. 3b. We observed a low level of NF- $\kappa B$ activation in the unstimulated condition and a dramatic enhancement after $2 \mathrm{~h}$ of co-culture with $3 \mathrm{~T}_{\mathrm{CD} 40 \mathrm{~L}}$ but not with $3 \mathrm{~T} 6_{\mathrm{CTRL}}$. Supershift assays using anti-NF- $\kappa \mathrm{B}$ p50 or anti-NF- $\mathrm{kB}$ p65 antibody were performed to characterise the nuclear proteins present in the complexes. The addition of anti-p50 mAb led to the disappearance of the lower band and a decrease in the upper band intensity, while the addition of anti-p65 mAb led to a decrease in the upper band intensity. This indicates that p50 and p65 subunits were major components of the NF- $\kappa B$ complexes present in CD40-activated duct cells. Specificity of NF- $\kappa B$-binding activity was demonstrated by competition with a 100 -fold excess of mutant or self-cold probes.

CD40 engagement induces TNF- $\alpha$ and IL- $1 \beta$ mRNA expression. As NF- $\kappa \mathrm{B}$ family members are known to control the expression of several cytokine genes, cytokine mRNA levels were quantified using real-time RT-PCR in Capan-2 cells cultured alone or in presence of $3 \mathrm{~T} 6_{\mathrm{CD} 40 \mathrm{~L}}$ or $3 \mathrm{~T} 6_{\mathrm{CTRL}}$. In a preliminary experiment where Capan-2 cells were separated from fibroblasts at serial time points of co-culture, we observed that exposure to CD40L resulted in a rapid induction of TNF- $\alpha$ and IL-1 $\beta$ mRNA peaking after $2 \mathrm{~h}$ (Fig. 4a), whereas the expression of IL-10, IL-12p40, IL-1RA and TGF- $\beta$ genes was not modified. Subsequent experiments where mRNA samples were prepared from Capan- 2 cells after $2 \mathrm{~h}$ of co-culture confirmed that contact with $3 \mathrm{~T} 6_{\mathrm{CD} 40 \mathrm{~L}}$ but not $3 \mathrm{~T} 6_{\text {CTRL }}$ resulted in accumulation of TNF- $\alpha$ mRNA and to a lower extent of IL-1 $1 \beta$ mRNA (Fig. $4 \mathrm{~b}$ and $4 \mathrm{c}$ ). We further assessed TNF- $\alpha$ secretion by protein quantification using Luminex technology. CD40 ligation induced TNF- $\alpha$ production by Capan- 2 cells, whereas such production was not observed with $3 \mathrm{~T}_{\mathrm{CTRL}}$ (Fig. 5).

Finally, we investigated the outcomes of CD40 ligation on isolated duct cells. In this setting, we confirmed that TNF- $\alpha$ was also produced by human primary duct cells upon CD40 engagement (Table 1). 
a

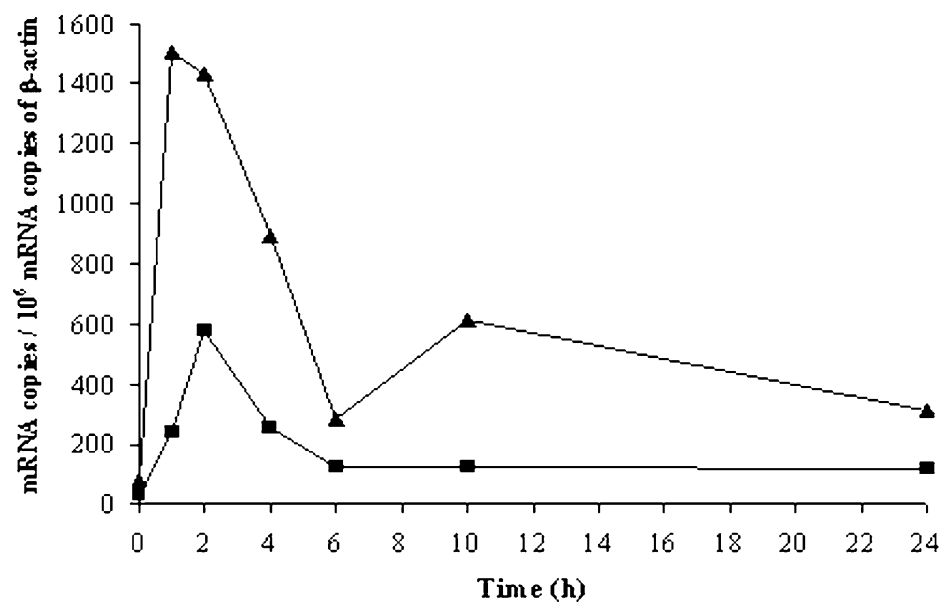

b

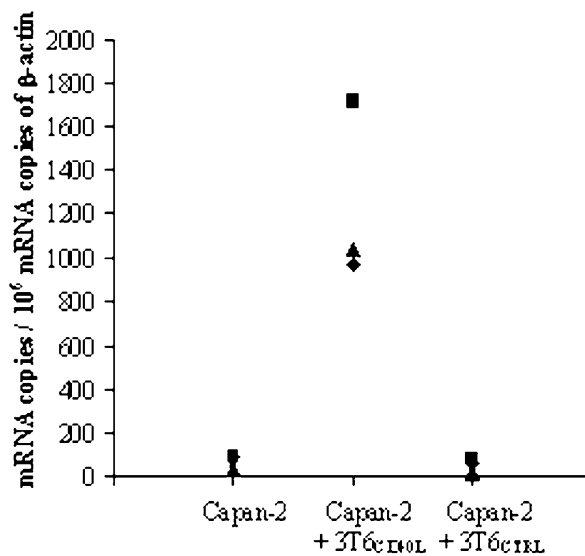

Fig. 4. Cytokine mRNA quantification using real-time RTPCR. a Time course determination of mRNA encoding TNF- $\alpha$ (triangle) or IL-1 $\beta$ (square): $2.5 \times 10^{5}$ Capan-2 cells were cocultured in the presence of $2.5 \times 10^{5} \mathrm{CD} 40 \mathrm{~L}$-transfected fibroblasts and were harvested at the indicated time points. Results were normalised against $\beta$-actin mRNA and expressed per $10^{6}$ mRNA copies of $\beta$-actin. TNF- $\alpha$ (b) and IL-1 $\beta$ (c) mRNA determination: $2.5 \times 10^{5}$ Capan- 2 cells were cultured alone or co-cultured in the presence of $2.5 \times 10^{5} \mathrm{CD} 40 \mathrm{~L}$-transfected $\left(3 \mathrm{~T}_{\mathrm{CD} 40 \mathrm{~L}}\right)$ or untransfected fibroblasts $\left(3 \mathrm{~T} 6_{\mathrm{CTRL}}\right)$. After $2 \mathrm{~h}$, cells were harvested and numbers of mRNA copies were determined using real-time RT-PCR. Results of three independent experiments performed in duplicate, normalised against $\beta$-actin mRNA and expressed per $10^{6}$ mRNA copies of $\beta$-actin are shown

\section{Discussion}

To our knowledge, this study provides the first evidence that human pancreatic duct cells express CD40. This observation is consistent with previous studies showing CD40 expression on other epithelial cell types $[13,15,16,18]$. CD40 signalling is rather complex as it involves protein tyrosine kinases, phosphoinositide-3 kinase, phospholipase $\mathrm{C} \gamma 2$ and serine/
C
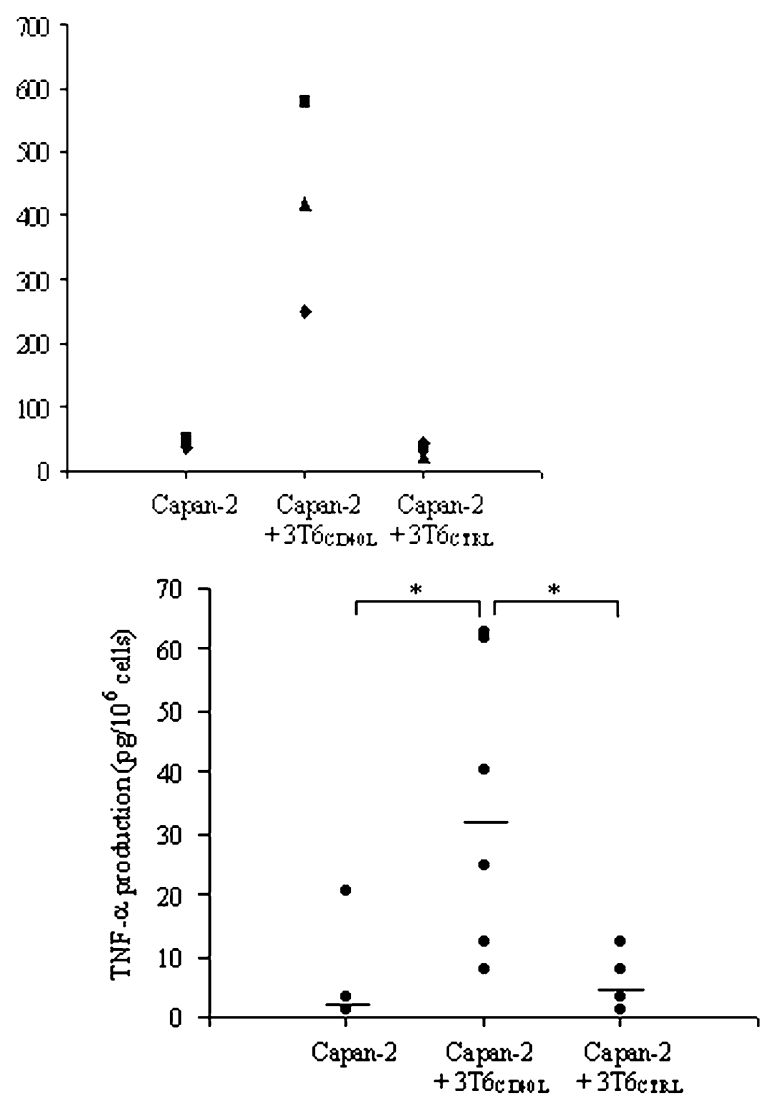

Fig. 5. $2.5 \times 10^{5}$ Capan- 2 cells were cultured alone or with either $2.5 \times 10^{5}$ CD40L-transfected fibroblasts $\left(3 \mathrm{~T}_{\mathrm{CD} 40 \mathrm{~L}}\right)$ or untransfected fibroblasts $\left(3 \mathrm{~T} 6_{\mathrm{CTRL}}\right)$. After $24 \mathrm{~h}$, levels of TNF- $\alpha$ were determined in the supernatants using Luminex technology. Results of six independent experiments are shown and horizontal bars represent the median. ${ }^{*} p<0.05$

threonine kinases. Although CD40 cytoplasmic domain lacks intrinsic catalytic activity, it associates with different families of signalling molecules, such as the TNF-receptor-associated factors, and leads to $\mathrm{NF}-\kappa \mathrm{B}$ activation $[20,21]$. Here, we provide evidence 
that CD40 ligation induces NF- $\kappa B$ activation in human pancreatic duct cells, revealing a potential new way to activate human pancreatic duct cells during immune processes. We found a rapid activation of NF$\kappa \mathrm{B}$ after stimulation with $\mathrm{CD} 40 \mathrm{~L}$, indicating a direct effect of CD40L on CD40 signalling. Supershift analyses revealed that the main activated form of NF- $\kappa B$ was represented by the p50/p65 heterodimers and to a lesser extent by p50/p50 homodimers, as previously observed in renal epithelial cells [13]. The NF- $\kappa B$ family member p65 harbours the transactivation domain, whereas p50 lacks this transactivation domain but still binds to specific DNA motif. This suggests that p50/p65 heterodimers activate transcription from NF-kB-binding sites on target genes, while the p50/p50 homodimers could function as transcriptional repressors [35, 36, 37].

Since NF- $\kappa B$ is known to regulate TNF- $\alpha$ and IL-1 $\beta$ gene activation [37], it is likely that the accumulation of TNF- $\alpha$ and IL-1 $\beta$ mRNA that we observed upon CD40 ligation is related at least partly to $\mathrm{NF}-\kappa \mathrm{B}$ activation.

The induction of TNF- $\alpha$ and IL- $1 \beta$ genes in duct cells might have important consequences for beta cells present in their vicinity. It has been proven that both cytokines have direct and indirect toxic effects on beta cells through the induction of reactive oxygen intermediates and nitric oxide [4, 38, 39, 40, 41, 42, 43]. Besides its toxic effect, TNF- $\alpha$ could also influence adaptative immune responses directed against beta cells. Indeed, TNF- $\alpha$ represents a major danger signal conditioning the fate of specific immune responses and interfering with tolerance induction [44, 45, 46]. However, the role of TNF- $\alpha$ in Type 1 diabetes is still controversial. Previous studies in animal models for Type 1 diabetes have clearly demonstrated that TNF- $\alpha$ could participate in the development of diabetes, while other studies have highlighted the role of TNF- $\alpha$ in silencing the autoimmune process, suggesting a dual role of TNF- $\alpha$ in the development of the disease based on the timing of TNF- $\alpha$ expression $[47,48,49,50,51,52,53]$.

In vivo, activation of duct cells through CD40 engagement could occur when activated $\mathrm{T}$ lymphocytes infiltrate islets, either during the autoimmune process or following graft transplantation. In the latter case, activated platelets expressing or releasing CD40L [22, $24]$ could also interact with CD40 on duct cells, since islet cell suspensions are directly injected into the portal vein. CD40-CD40L interactions at the pancreatic duct cell level could therefore contribute to beta cell damage in Type 1 diabetes and after islet transplantation. So far, the beneficial effects of CD40L blockade in preventing experimental autoimmune diabetes [28, 29] and islet graft rejection [54, 55, 56] has been attributed to disruption of the interactions between antigen-presenting cells and $\mathrm{T}$ lymphocytes [26]. We suggest that CD40-CD40L targeted therapy could also act by preventing the local release of inflammatory cytokines by duct cells in the vicinity of pancreatic islets.

Acknowledgements. This work was supported by a grant from the Juvenile Diabetes Research Foundation. O. Vosters is supported by SMB-Galephar (Belgium). C. Beuneu and V. Verhasselt are supported by the National Fund for Scientific Research (Belgium). The authors wish to thank P. Stordeur for providing primers and probes for RT-PCR and L. Bouwens for providing Capan-2 cell lines.

\section{References}

1. Bouwens L, Pipeleers DG (1998) Extra-insular beta cells associated with ductules are frequent in adult human pancreas. Diabetologia 41:629-633

2. Bonner-Weir S, Baxter LA, Schuppin GT, Smith FE (1993) A second pathway for regeneration of adult exocrine and endocrine pancreas. A possible recapitulation of embryonic development. Diabetes 42:1715-1720

3. Pavlovic D, Winkel M van de, Auwera B van der et al. (1997) Effect of interferon-gamma and glucose on major histocompatibility complex class I and class II expression by pancreatic beta- and non-beta-cells. J Clin Endocrinol Metab 82:2329-2336

4. Pavlovic D, Chen MC, Bouwens L, Eizirik DL, Pipeleers D (1999) Contribution of ductal cells to cytokine responses by human pancreatic islets. Diabetes 48:29-33

5. Bonner-Weir S, Taneja M, Weir GC et al. (2000) In vitro cultivation of human islets from expanded ductal tissue. Proc Natl Acad Sci USA 97:7999-8004

6. Bogdani M, Lefebvre V, Buelens N et al. (2003) Formation of insulin-positive cells in implants of human pancreatic duct cell preparations from young donors. Diabetologia 46:830-838

7. Gao R, Ustinov J, Pulkkinen MA, Lundin K, Korsgren O, Otonkoski T (2003) Characterisation of endocrine progenitor cells and critical factors for their differentiation in human adult pancreatic cell culture. Diabetes 52:2007-2015

8. Pipeleers D, Hoorens A, Marichal-Pipeleers M, Van de Casteele M, Bouwens L, Ling Z (2001) Role of pancreatic beta-cells in the process of beta-cell death. Diabetes 50 [Suppl 1]:S52-S57

9. Ling Z, Pipeleers DG (1996) Prolonged exposure of human beta cells to elevated glucose levels results in sustained cellular activation leading to a loss of glucose regulation. J Clin Invest 98:2805-2812

10. Keymeulen B, Ling Z, Gorus FK et al. (1998) Implantation of standardized beta-cell grafts in a liver segment of IDDM patients: graft and recipients characteristics in two cases of insulin-independence under maintenance immunosuppression for prior kidney graft. Diabetologia 41:452-459

11. Janeway CA Jr, Medzhitov R (2002) Innate immune recognition. Annu Rev Immunol 20:197-216

12. Vives-Pi M, Somoza N, Fernandez-Alvarez J et al. (2003) Evidence of expression of endotoxin receptors CD14, tolllike receptors TLR4 and TLR2 and associated molecule MD-2 and of sensitivity to endotoxin (LPS) in islet beta cells. Clin Exp Immunol 133:208-218

13. Woltman AM, Haij S de, Boonstra JG, Gobin SJ, Daha MR, Kooten C van (2000) Interleukin-17 and CD40-ligand synergistically enhance cytokine and chemokine production by renal epithelial cells. J Am Soc Nephrol 11:20442055 
14. Propst SM, Denson R, Rothstein E, Estell K, Schwiebert LM (2000) Proinflammatory and Th2-derived cytokines modulate CD40-mediated expression of inflammatory mediators in airway epithelia: implications for the role of epithelial CD40 in airway inflammation. J Immunol $165: 2214-2221$

15. Afford SC, Ahmed-Choudhury J, Randhawa S et al. (2001) CD40 activation-induced, Fas-dependent apoptosis and NF-kappaB/AP-1 signalling in human intrahepatic biliary epithelial cells. FASEB J 15:2345-2354

16. Propst SM, Estell K, Schwiebert LM (2002) CD40mediated activation of NF-kappa B in airway epithelial cells. J Biol Chem 277:37054-37063

17. Haij S de, Woltman AM, Bakker AC, Daha MR, Kooten C van (2002) Production of inflammatory mediators by renal epithelial cells is insensitive to glucocorticoids. Br J Pharmacol 2002 137:197-204

18. Amsellem C, Durieu, Chambe MT, Peyrol S, Pacheco Y (2002) In vitro expression of fas and CD40 and induction of apoptosis in human cystic fibrosis airway epithelial cells. Respir Med 96:244-249

19. Berberich I, Shu GL, Clark EA (1994) Cross-linking CD40 on B cells rapidly activates nuclear factor-kappa B. J Immunol 153:4357-4366

20. Kooten C van, Banchereau J (1997) Functions of CD40 on B cells, dendritic cells and other cells. Curr Opin Immunol 9:330-337

21. Kooten C van, Banchereau J (2000) CD40-CD40 ligand. J Leukoc Biol 67:2-17

22. Henn V, Slupsky JR, Grafe M et al. (1998) CD40 ligand on activated platelets triggers an inflammatory reaction of endothelial cells. Nature 391:591-594

23. Freedman JE (2003) CD40 ligand--assessing risk instead of damage? N Engl J Med 348:1163-1165

24. Heeschen C, Dimmeler S, Hamm CW et al. (2003) Soluble CD40 ligand in acute coronary syndromes. N Engl J Med 348:1104-1111

25. Caux C, Massacrier C, Vanbervliet B et al. (1994) Activation of human dendritic cells through CD40 cross-linking. J Exp Med 180:1263-1272

26. Grewal IS, Flavell RA (1998) CD40 and CD154 in cellmediated immunity. Annu Rev Immunol 16:111-135

27. O'Sullivan BJ, Thomas R (2002) CD40 ligation conditions dendritic cell antigen-presenting function through sustained activation of NF-kappaB. J Immunol 168:5491-5498

28. Homann D, Jahreis A, Wolfe T et al. (2002) CD40L blockade prevents autoimmune diabetes by induction of bitypic NK/DC regulatory cells. Immunity 16:403-415

29. Moore WV, Chu W, Tong PY et al. (2002) Prevention of autoimmune diabetes in the DRBB rat by CD40/154 blockade. J Autoimmun 19:139-145

30. De Breuck S, Lardon J, Rooman I, Bouwens L (2003) Netrin-1 expression in fetal and regenerating rat pancreas and its effect on the migration of human pancreatic duct and porcine islet precursor cells. Diabetologia 46:926933

31. Aksoy E, Amraoui Z, Goriely S, Goldman M, Willems F (2002) Critical role of protein kinase C epsilon for lipopolysaccharide-induced IL-12 synthesis in monocytederived dendritic cells. Eur J Immunol 32:3040-3049

32. Osborn L, Kunkel S, Nabel GJ (1989) Tumor necrosis factor alpha and interleukin 1 stimulate the human immunodeficiency virus enhancer by activation of the nuclear factor kappa B. Proc Natl Acad Sci USA 86:2336-2340

33. Stordeur P, Zhou L, Goldman M (2002) Analysis of spontaneous mRNA cytokine production in peripheral blood. J Immunol Methods 261:195-197
34. Stordeur P, Zhou L, Byl B et al. (2003) Immune monitoring in whole blood using real-time PCR. J Immunol Methods 276:69-77

35. May MJ, Ghosh S (1997) Rel/NF-kappa B and I kappa B proteins: an overview. Semin Cancer Biol 8:63-73

36. Lee JI, Burckart GJ (1998) Nuclear factor kappa B: important transcription factor and therapeutic target. J Clin Pharmacol 38:981-993

37. Li Q, Verma IM (2002) NF-kappaB regulation in the immune system. Nat Rev Immunol 2:725-734

38. Corbett JA, McDaniel ML (1995) Intraislet release of interleukin 1 inhibits beta cell function by inducing beta cell expression of inducible nitric oxide synthase. J Exp Med 181:559-568

39. Arnush M, Heitmeier MR, Scarim AL, Marino MH, Manning PT, Corbett JA (1998) IL-1 produced and released endogenously within human islets inhibits beta cell function. J Clin Invest 102:516-526

40. Ling Z, Van de Casteele M, Eizirik DL, Pipeleers DG (2000) Interleukin-1beta-induced alteration in a beta-cell phenotype can reduce cellular sensitivity to conditions that cause necrosis but not to cytokine-induced apoptosis. Diabetes 49:340-345

41. Hoorens A, Stange G, Pavlovic D, Pipeleers D (2001) Distinction between interleukin-1-induced necrosis and apoptosis of islet cells. Diabetes 50:551-557

42. Thomas HE, Darwiche R, Corbett JA, Kay TW (2002) Interleukin-1 plus gamma-interferon-induced pancreatic beta-cell dysfunction is mediated by beta-cell nitric oxide production. Diabetes 51:311-316

43. Tabatabaie T, Vasquez-Weldon A, Moore DR, Kotake Y (2003) Free radicals and the pathogenesis of type 1 diabetes: beta-cell cytokine-mediated free radical generation via cyclooxygenase-2. Diabetes 52:1994-1999

44. Gallucci S, Matzinger P (2001) Danger signals: SOS to the immune system. Curr Opin Immunol 13:114-119

45. Matzinger P (2002) The danger model: a renewed sense of self. Science 296:301-305

46. O'Shea JJ, Ma A, Lipsky P (2002) Cytokines and autoimmunity. Nat Rev Immunol 2:37-45

47. Jacob CO, Aiso S, Michie SA, McDevitt HO, Acha-Orbea $\mathrm{H}$ (1990) Prevention of diabetes in nonobese diabetic mice by tumor necrosis factor (TNF): similarities between TNF-alpha and interleukin 1. Proc Natl Acad Sci USA 87:968-972

48. Yang XD, Tisch R, Singer SM et al. (1994) Effect of tumor necrosis factor alpha on insulin-dependent diabetes mellitus in NOD mice. I. The early development of autoimmunity and the diabetogenic process. J Exp Med 180:995-1004

49. Grewal IS, Grewal KD, Wong FS, Picarella DE, Janeway CA Jr, Flavell RA (1996) Local expression of transgene encoded TNF alpha in islets prevents autoimmune diabetes in nonobese diabetic (NOD) mice by preventing the development of auto-reactive islet-specific T cells. J Exp Med 184:1963-1974

50. Rabinovitch A, Suarez-Pinzon WL, Sorensen O, Rajotte RV, Power RF (1997) TNF-alpha down-regulates type 1 cytokines and prolongs survival of syngeneic islet grafts in nonobese diabetic mice. J Immunol 159:6298-6303

51. Green EA, Flavell RA (2000) The temporal importance of TNF-alpha expression in the development of diabetes. Immunity 12:459-469

52. Christen U, Wolfe T, Mohrle U et al. (2001) A dual role for TNF-alpha in type 1 diabetes: islet-specific expression abrogates the ongoing autoimmune process when induced late but not early during pathogenesis. J Immunol 166:7023-7032 
53. Skak K, Guerder S, Picarella DE, Brenden N, Flavell RA, Michelsen BK (2003) TNF-alpha impairs peripheral tolerance towards beta-cells, and local costimulation by B7.1 enhances the effector function of diabetogenic T cells. Eur J Immunol 33:1341-1350

54. Parker DC, Greiner DL, Phillips NE et al. (1995) Survival of mouse pancreatic islet allografts in recipients treated with allogeneic small lymphocytes and antibody to CD40 ligand. Proc Natl Acad Sci USA 92:9560-9564
55. Kover KL, Geng Z, Hess DM, Benjamin CD, Moore WV (2000) Anti-CD154 (CD40L) prevents recurrence of diabetes in islet isografts in the DR-BB rat. Diabetes 49:1666-1670

56. Phillips NE, Markees TG, Mordes JP, Greiner DL, Rossini AA (2003) Blockade of CD40-mediated signalling is sufficient for inducing islet but not skin transplantation tolerance. J Immunol 170:3015-3023 